\title{
Bud Formation in Saccharomyces cerevisiae and a Comparison with the Mechanism of Cell Division in Other Yeasts
}

\author{
By R. MARCHANT AND D. G. SMITH \\ Department of Botany, University College, Gower Street, London, W.C. I
}

(Accepted for publication 27 March 1968)

\begin{abstract}
SUMMAR Y
Bud formation in Saccharomyces cerevisiae occurs by an extension of the entire parent cell wall, as described previously. The dividing walls between the bud and the parent cell are laid down simultaneously, but the bud septum is completed more rapidly. The dividing walls separate before the bud is mature. Finally, the bud is released by the breakdown of the outer wall. A comparison between bud formation in S. cerevisiae and Rhodotorula glutinis reveals basic differences in the mechanisms which can be related to structures in mycelial fungi.
\end{abstract}

\section{INTRODUCTION}

There have been a number of investigations of the ultrastructure of Saccharomyces cerevisiae, commencing with the early studies of Agar \& Douglas (1955) through to the freeze-etch study of Moor (1967). S. cerevisiae has proved a troublesome organism to study in the electron microscope as it is difficult to obtain satisfactory fixation using conventional techniques. This accounts for the confusion over certain aspects of yeast cytology and especially bud formation. Only recently (McClary \& Bowers, 1965) has it been established unequivocally that the normal bud wall in $S$. cerevisiae is a continuation of the parent wall, and indeed that the bud is always surrounded by a wall layer. Although the relationship between the parent wall and the bud wall is now established there still remains the problem of how the bud is delimited and released from the parent cell. Marchant \& Smith (1967) have shown that in Rhodotorula glutinis the bud wall is not formed from a direct continuation of the parent wall, but from a new wall layer formed within the parent cell. The different mode of formation of the bud in these two species immediately provokes a discussion on whether the two mechanisms have different origins or whether one is a simple modification of the other. In this paper we shall describe the budding process in $S$. cerevisiae in more detail than has been done previously and compare it with the already described process in $R$. glutinis and other yeasts. We shall also attempt to relate the differences to the existing phylogenetic schemes.

\section{METHODS}

The organism used for this study was Saccharomyces cerevisiae strain 2 I, kindly supplied by Dr D. Wilkie. This haploid strain, in common with most other haploid strains, tends to have several buds developing simultaneously. It was grown in a modified Wickerham medium (Wickerham, 1946) with $2 \%(\mathrm{w} / \mathrm{v})$ melibiose as carbon source. This non-repressing fermentable substrate was selected as it was found to give 
better preservation of cytological detail than glucose. The cells were harvested towards the end of the active growth phase, fixed and embedded according to Marchant \& Smith (1967). Sections were cut with a diamond knife on an LKB ultratome, and poststained with saturated alcoholic uranyl acetate (Gibbons \& Grimstone, 1960) and lead citrate (Reynolds, 1963). The material was examined in a Siemens Elmiskop I electron microscope.

\section{RESULTS}

In the youngest bud stages (Pl. I, fig. I) the bud wall is obviously a continuation of the parent cell wall, as established by McClary \& Bowers (1965). The young bud wall is, however, slightly thinner than the parent wall at this stage, and probably contains a certain amount of parent cell wall material as suggested by Chung, Hawirko \& Isaac (I965). At the junction of the parent and bud cell walls, on the inner surface, can be seen an encircling layer of less electron-opaque wall material. The wall at this point is also thicker than at other parts of the parent cell, probably as a result of a modification of pre-existing wall material. Endoplasmic reticulum can often be observed in the young bud, as reported by Marchant \& Smith (1967) and Moor (1967).

As the bud grows the electron-transparent region in the wall becomes more extensive and better defined (Pl. I, fig. 2). At this stage organelles become evident in the bud, and the endoplasmic reticulum still appears to be active. Finally the bud reaches almost the same size as the parent cell and possesses a full complement of organelles, but there is no evidence of septum formation separating the bud from the parent cell (Pl. I, fig. 3). Intermediate stages in septum formation are difficult to distinguish satisfactorily from oblique sections, but in our opinion the micrographs in Pl. I, fig. 4 and Pl. 2, fig. 5 show the centripetal formation of the septa. The bud septum and the parent cell septum are formed simultaneously but it appears that the two septa are maintained as separate entities from the time of their formation; the parent cell septum is initially thinner and undergoes some modification in structure during development (Pl. 2, fig. 6, 7). The electron-transparent wall regions lose some of their integrity during the formation of the septa, but this is regained when the septa are mature.

The bud wall is initially continuous with the bud septum and with the parent cell wall (Pl. 2, fig. 8). Later the bud wall and the parent cell wall become separate (Pl. 3, fig. 9), possibly due to an outward increase in extent of the electron-transparent layer. The bud scar left on the parent cell after the release of the bud (Pl. 3, fig. 10) is essentially similar in appearance to that observed in Rhodotorula glutinis (Marchant \& Smith, 1967). The concavity in the bud cell in the region of the birth scar gradually disappears until it is no longer visible in sections. The stages in bud formation in Saccharomyces cerevisiae are summarized in Fig. I.

\section{DISCUSSION}

We have confirmed the assertion of McClary \& Bowers (1965) that the bud wall in Saccharomyces cerevisiae is continuous with the existing parent cell wall. In addition we have demonstrated that the two wall layers dividing the parent cell and the bud are separate from each other long before the bud is mature. The bud is released from the parent cell by the cleavage of the outer wall where it is continuous with the parent cell wall. Rhodotorula glutinis is somewhat different in that the bud wall is not a continua- 
tion of the major part of the parent cell wall. The dividing wall layers in this instance are not separate from each other during bud development, but cleave to release the bud (Fig. 2). In this respect a parallel can be drawn between the release of the daughter cell in $R$. glutinis and the separation of the fission cells in Schizosaccharomyces octosporus (Conti \& Naylor, I959).

Nečas \& Svoboda (1967) in their study of regenerating protoplasts of Saccharomyces cerevisiae described a budding process similar to that described for Rhodotorula glutinis (Marchant \& Smith, 1967). They do say, however, that the walls of buds formed from normal cells and from regenerating protoplasts may develop by different
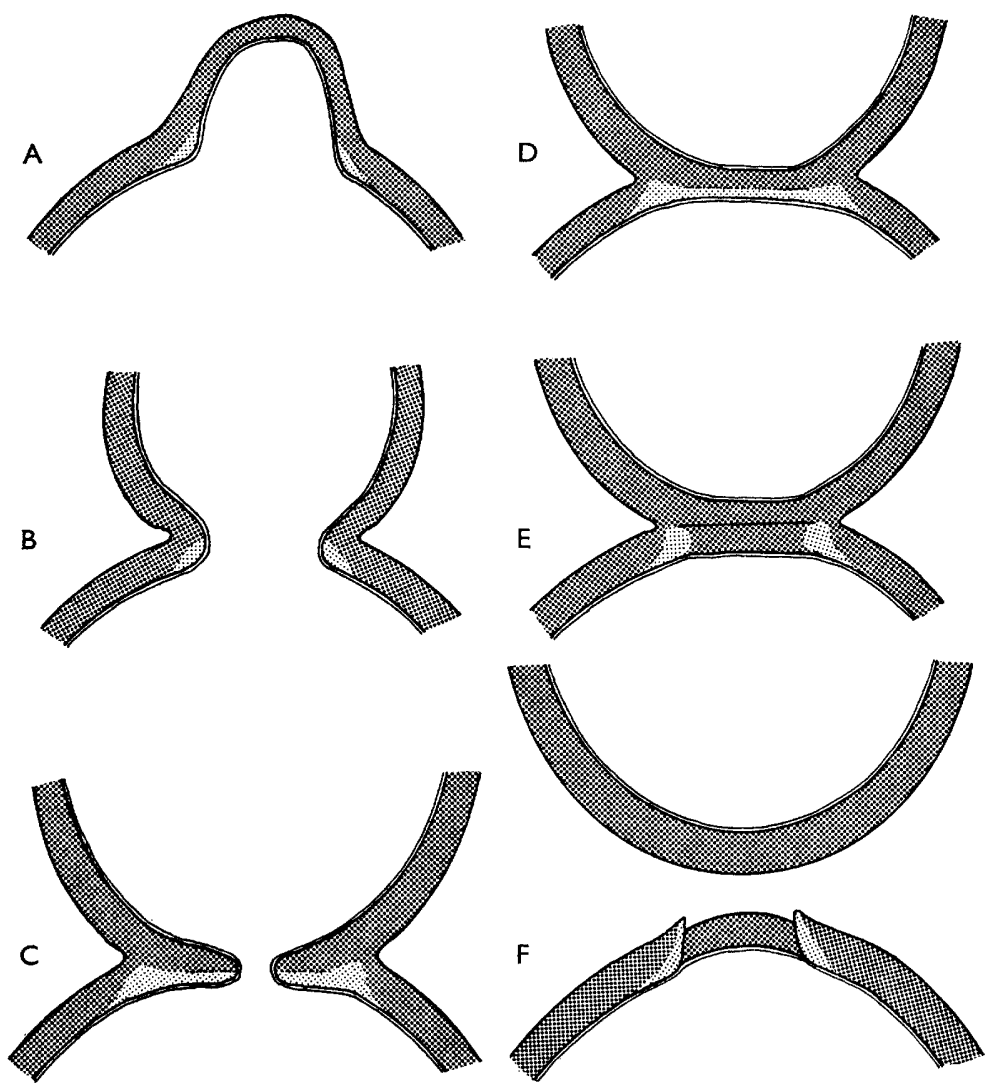

Fig. I. Diagrammatic representation of the proposed stages of bud formation in Saccharomyces cerevisiae.

mechanisms. The scheme which they propose for budding in the regenerating protoplasts is obviously at variance with the mechanism in normal cells determined both from our observations and those of previous workers (McClary \& Bowers, 1965; Hagedorn, 1964).

It is now certain that young buds in these yeasts are surrounded by a wall layer from their inception and do not result from a naked 'blow out' as suggested by Nickerson \& Falcone (1959) and Nickerson (1963). Chung et al. (1965) have further shown that the bud contains little of the original parent cell-wall material and, in view of the fact that 
the bud cell wall is always of a substantial thickness, this implies that cell wall synthesis in Saccharomyces cerevisiae must proceed rapidly to maintain bud growth. Moor (1967) noted that vesicles from the endoplasmic reticulum seemed to initiate bud formation in $S$. cerevisiae, and suggested that the vesicles carried the wall plasticizing enzymes to the site of incipient bud formation. Similar endoplasmic reticulum and vesicles were noted in developing buds of Rhodotorula glutinis by Marchant \& Smith (1967), who proposed that wall material precursors might be transported in these vesicles. This proposal was based on the work of Marchant, Peat \& Banbury (1967) on the growth of fungal hyphae. Obviously there must be some modification of the parent cell wall at the site of bud formation in yeasts and therefore the two proposals for the possible function of the endoplasmic reticulum and vesicles are not mutually exclusive.

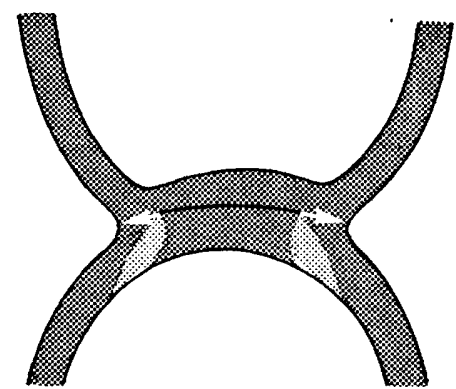

Saccharomyces cerevisiae

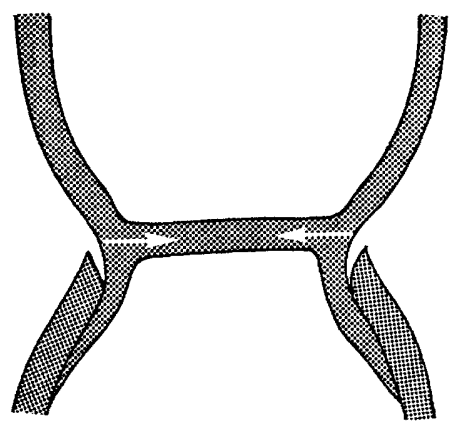

Rhodotorula glutinis

Fig. 2. Diagram illustrating the different modes of bud separation in Saccharomyces cerevisiae and Rhodotorula glutinis. The arrows indicate the direction of cleavage.

It appears that the derivation of the bud wall in Saccharomyces cerevisiae and Rhodotorula glutinis differs quite considerably. The bud wall of $S$. cerevisiae is a continuation of the whole of the parent cell wall rather than some of its constituent layers. Marchant \& Smith (1967) stated that the bud wall in $R$. glutinis is formed from an entirely new wall layer produced inside the existing parent cell wall. Prusso \& Wells (1967) in their study of Sporobolomyces roseus suggested that when the organism buds, produces a hyphal strand or gives rise to a sterigma, the outer wall layers are ruptured by the innermost pair of existing wall layers. They also stated that published micrographs of Rhodotorula species showed budding of this type. A similar controversy has arisen over spore germination in several filamentous fungi; Hawker \& Abbot (I963) observed the formation of a new wall layer within the spores of Rhizopus species prior to germination. This interpretation was criticized by Tanaka (I966), who suggested that it might be simply a visualization of existing wall layers rather than de novo synthesis of a new layer. A similar mode of germination was, however, reported by Marchant $(1966 a, b)$ in Fusarium culmorum conidia. It is therefore feasible that the bud wall in $R$. glutinis may also be formed from a new wall layer produced within the parent cell rather than from existing wall layers.

When a comparison is made between budding and fission in the various yeasts the 
similarities between all the processes become apparent. In all the budding systems examined new cell wall material is incorporated apically with respect to the plane of division. Therefore the new cell wall material is deposited in the bud wall, which is composed almost entirely of new material, although this deposition may not occur evenly round the bud (Chung et al. I964). In the fission yeasts apical incorporation of wall material has also been observed using morphological features of the cells as markers (Mitchison, 1957) and by fluorescent antibody techniques (May, 1962). The portions of the daughter cells which have wall material synthesized after the initiation

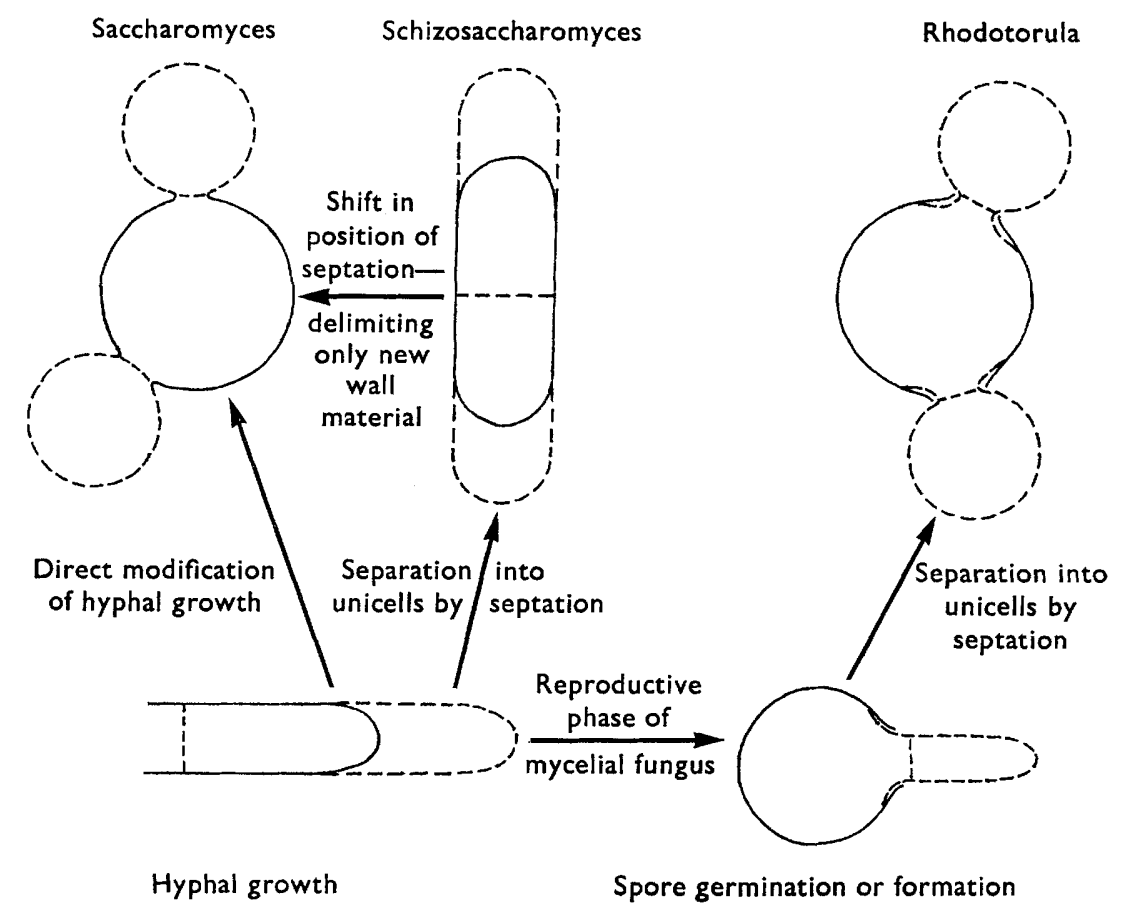

Fig. 3. Possible relationships between the growth forms of yeasts and mycelial fungi. Broken lines represent regions of new wall synthesis.

of division are summarized in Fig. 3. The budding species have entirely new cell walls around their daughter cells, while the fission species have some of the parent cell wall remaining in the daughter cells.

The yeasts represent an ill-defined group of morphologically similar species probably with polyphyletic origins. A discussion of the various modes of division, examined at the ultrastructural level, and comparisons with other fungi, may give a clue to possible lines of development of the yeast growth form. The apical addition of wall material can be compared directly with the growth of the fungal hyphae; in the unicellular condition some of the polarity of growth has necessarily been lost. In both Saccharomyces cerevisiae and Schizosaccharomyces species the growth of the daughter cell wall is similar to hyphal growth, producing a continuous extension of a single wall structure. In the yeasts septation gives rise to unicells rather than a septate mycelium; 
some mycelial fungi, however, are capable of existing as yeast-like cells under certain conditions which substantiates the hypothesis that the yeast condition is not far removed from the mycelial condition. Daughter-cell formation in S. cerevisiae and Schizosaccharomyces species could therefore be a direct modification of hyphal growth. In $S$. cerevisiae, however, the position of septation has been moved so that only new wall material is cut-off in the bud, in contrast with the semiconservative fission of Schizosaccharomyces species. The system of budding in $S$. cerevisiae may have been derived from the fission mechanism or may have arisen independently from the hyphal form. Bud formation in Rhodotorula glutinis, in contrast, is comparable with the reproductive stages of certain mycelial fungi: spore formation (Trinci, Peat \& Banbury, 1968; Lowry, Durkee \& Susmann, 1967) and spore germination (Hawker \& Abbott, 1963; Marchant, I966a, b) (see Fig. 3). This suggests that the R. glutinis type of budding may have arisen from the reproductive phase of some mycelial fungi, a view to some extent supported by the fact that this mechanism can be traced in Sporobolomyces roseus (Prusso \& Wells, 1967), which is thought to be a modified basidiospore system (Lodder, Slooff \& Kreger-van Rij, I958).

We would like to thank Dr D. Wilkie for kindly supplying Saccharomyces cerevisiae strain $2 \mathrm{I}$.

\section{REFERENCES}

Agar, H. D. \& Douglas, H. C. (1955). Studies of budding and cell wall structure of yeast. J. Bact. 7o, 427.

Chung, K. L., Hawirko, R.Z. \& IsaAc, P. K. (1965). Cell wall replication in Saccharomyces cerevisiae. Can. J. Microbiol. II, 953.

ConTI, S. F. \& NAYLOR, H. B. (1959). Electron microscopy of ultrathin sections of Schizosaccharomyces octosporus. I. Cell division. J. Bact. 78, 868.

Gibbons, I. R. \& GRImStone, A. V. (I960). On flagellar structure in certain flagellates. J. biophys. biochem. Cytol. 7, 697.

Hagedorn, H. (1964). Die Feinstruktur der Hefezellen. I. Zellwand, Sporen, Cytoplasma, Endoplasmatisches Retikulum. Protoplasma 58, 250.

HAWKER, L. E. \& ABBotT, P. MCV. (I963). An electron microscope study of maturation and germination of sporangiospores of two species of Rhizopus. J. gen. Microbiol. 32, 295.

Lodder, J., SLooff, W. C. \& Kreger-van RIJ, N. J. W. (1958). The classification of yeasts. In The Chemistry and Biology of Yeasts. Ed. by A. H. Cook, I. New York: Academic Press.

Lowry, R. L., DurkeE, T. L. \& SusSman, A. S. (1967). Ultrastructural studies of microconidium formation in Neurospora crassa. J. Bact. 94, I757.

Marchant, R. (1966a). Fine structure and spore germination in Fusarium culmorum. Ann. Bot. N.S. 30, 44I.

MARChant, R. (1966b). Wall structure and spore germination in Fusarium culmorum. Ann. Bot. N.S. 30, 821 .

MARChANT, R. \& SмITH, D. G. (1967). Wall structure and bud formation in Rhodotorula glutinis. Arch. Mikrobiol. 58, 248.

Marchant, R., Peat, A. \& Banbury, G. H. (1967). The ultrastructural basis of hyphal growth. New Phytol. 66, 623.

MAY, J. W. (1962). Sites of cell wall extension demonstrated by the use of fluorescent antibody. Expl Cell Res. 27, 170.

MCClARY, D. O. \& Bowers, W. D. (1965). The integrity of the cell wall during bud formation in yeasts. Can. J. Microbiol. II, 447 .

Mitchison, J. M. (1957). The growth of single cells. I. Schizosaccharomyces pombe. Expl Cell Res. I3, 244 .

Moor, H. (1967). Endoplasmic reticulum as the initiator of bud formation in yeast (S. cerevisiae). Arch. Mikrobiol. 57, 135. 

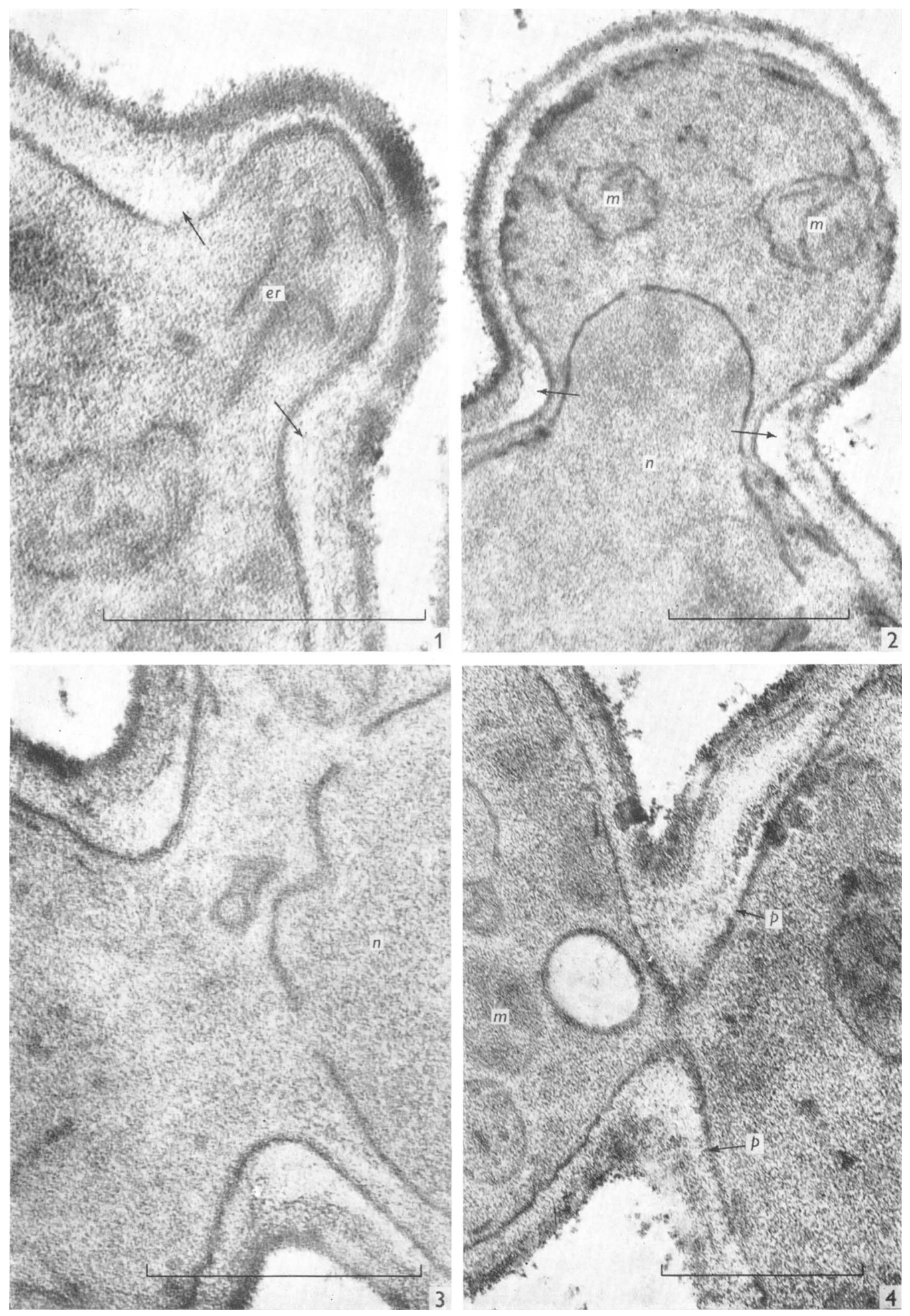

R. MARCHANT AND D. G. SMITH

(Facing p. I68) 
Journal of General Microbiology, Vol. 53, No. 2

Plate 2
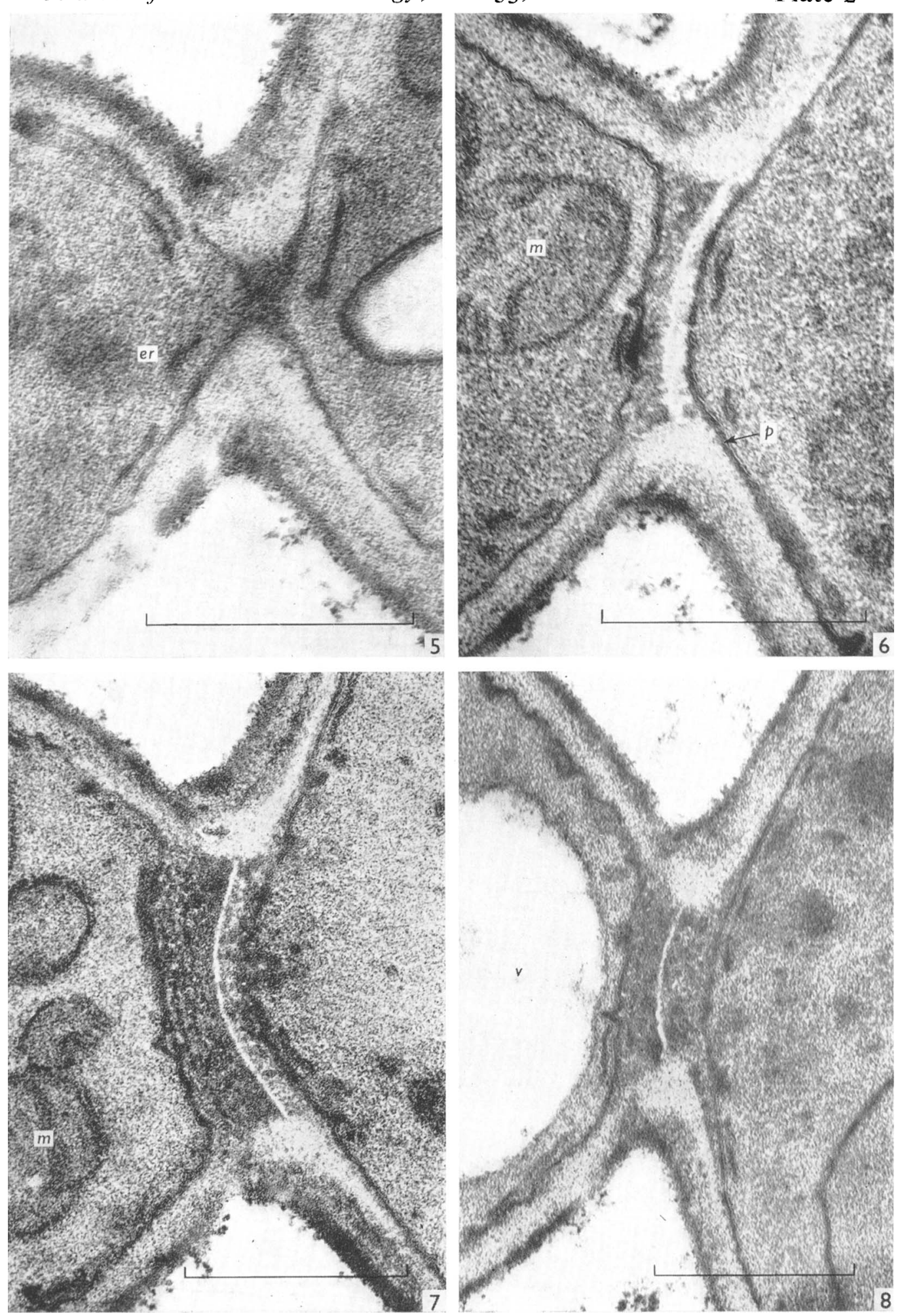

R. MARCHANT AND D. G. SMITH 

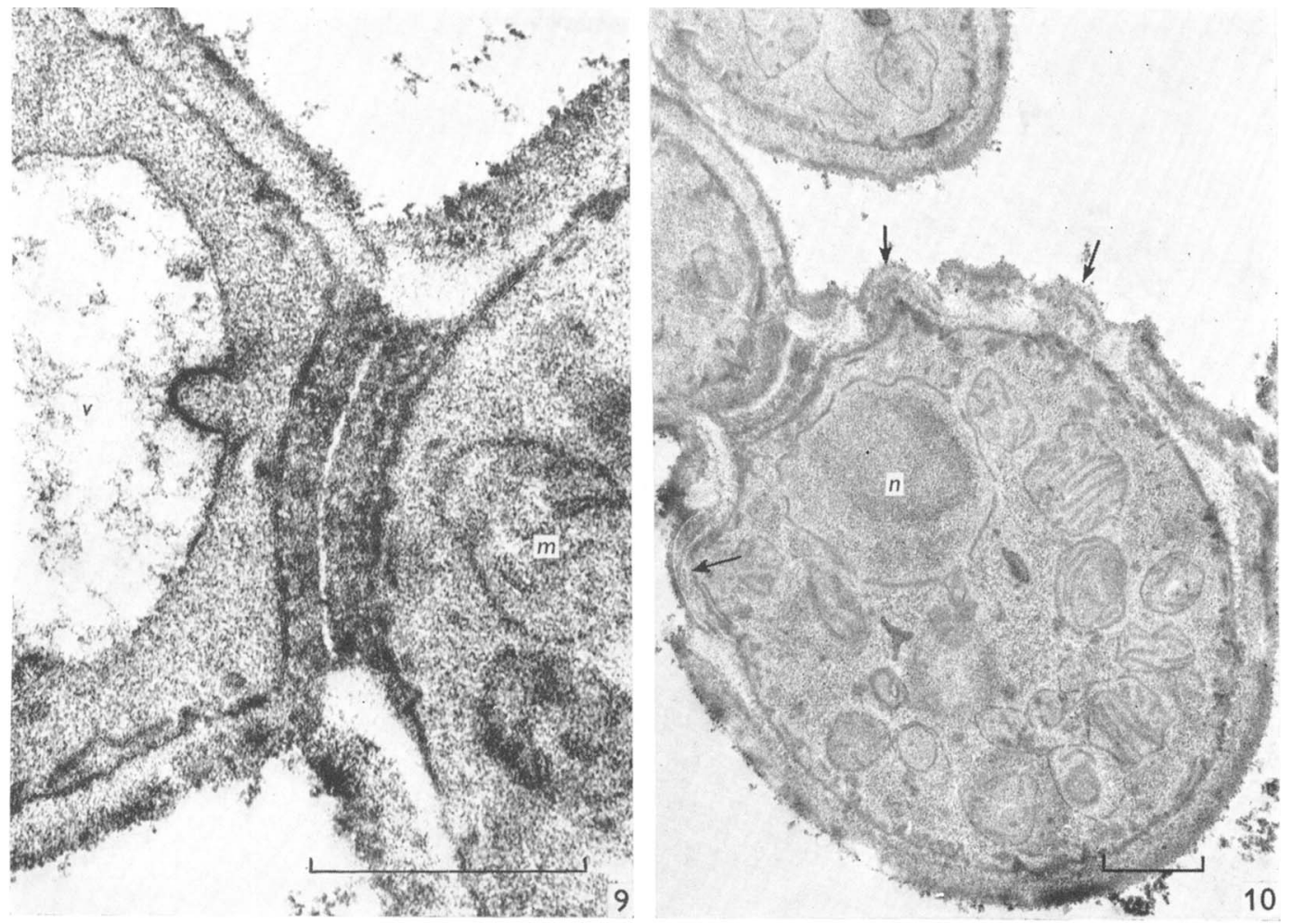

R. MARCHANT AND D. G. SMITH 
NeČAs, O. \& SvoBodA, A. (1967). Mechanism of regeneration of yeast protoplasts. IV. Electron microscopy of regenerating protoplasts. Folia biol., Praha 13, 379.

NiCKERSON, W. J. (1963). Symposium on biochemical basis of morphogenesis in fungi. IV. Molecular basis of form in yeasts. Bact. Rev. 27, 305 .

NiCKERSON, W. J. \& FAlCONE, G. (I959). Function of protein disulfide reductase in cellular division of yeasts. In Sulfur in Proteins. Ed. by R. Benesch et al. p. 409. New York and London: Academic Press.

Prusso, D. C. \& Wells, K. (1967). Sporobolomyces roseus. I. Ultrastructure. Mycologia 59, 337.

REYNOLDS, E.S. (1963). The use of lead citrate at high pH as an electron-opaque stain in electron microscopy. J. Cell. Biol. 17, 208.

TANAKA, K. (1966). Change in ultrastructure of Aspergillus oryzae conidia during germination. J. gen. appl. Microbiol., Tokyo 12, 239.

Trinci, A. P. J., Peat, A. \& Banbury, G. H. (I968). Fine structure of phialide and conidiospore development in Aspergillus giganteus (Whemer). Ann. Bot. N.S. (in the Press).

WiCKerHAM, L. J. (1946). A critical evaluation of the nitrogen assimilation tests commonly used in the classification of yeasts. J. Bact. 52, 293 .

\section{EXPLANATION OF PLATES}

Abbreviations: $e r$, endoplasmic reticulum; $m$, mitochondrion; $n$, nucleus; $p$, plasmalemma; $v$, vacuole. Scale lines represent $0.5 \mu$. In figs. 3-Io the buds are situated to the left of the micrographs.

\section{Plate I}

Fig. I. Early stage in bud formation, showing continuity of bud and parent walls and initial development of electron-transparent wall areas (arrowed).

Fig. 2. Small bud already possessing some organelles and with clearly defined electron-transparent wall areas (arrowed).

Fig. 3. Junction of parent and daughter cells immediately prior to septum formation.

Fig. 4. Initial stage in centripetal formation of cross septa.

Plate 2

Fig. 5. Further stage in the development of transeptation.

Fig. 6. Junction of parent and daughter cells soon after completion of the septa, showing the very thin cell septum.

Fig. 7. Section showing the two septa separate and unequally developed.

Fig. 8. Septa fully developed and separated. Bud wall still continuous with parent cell wall.

$$
\text { Plate } 3
$$

Fig. 9. Septa fully developed; bud wall beginning to become delimited from the parent wall. Fig. Io. Old cell with several bud scars (arrowed), illustrating the permanence of the electron-transparent wall areas. 